San Jose State University

SJSU ScholarWorks

Master's Theses

Master's Theses and Graduate Research

1995

\title{
Effects of off-highway vehicles on seasonal home ranges and daily activity levels of black-tailed deer
}

Kristina Timmerman

San Jose State University

Follow this and additional works at: https://scholarworks.sjsu.edu/etd_theses

\section{Recommended Citation}

Timmerman, Kristina, "Effects of off-highway vehicles on seasonal home ranges and daily activity levels of black-tailed deer" (1995). Master's Theses. 1035.

DOI: https://doi.org/10.31979/etd.qutk-3dxm

https://scholarworks.sjsu.edu/etd_theses/1035

This Thesis is brought to you for free and open access by the Master's Theses and Graduate Research at SJSU ScholarWorks. It has been accepted for inclusion in Master's Theses by an authorized administrator of SJSU ScholarWorks. For more information, please contact scholarworks@sjsu.edu. 


\section{INFORMATION TO USERS}

This manuscript has been reproduced from the microfilm master. UMI films the text directly from the original or copy submitted. Thus, some thesis and dissertation copies are in typewriter face, while others may be from any type of computer printer.

The quality of this reproduction is dependent upon the quality of the copy submitted. Broken or indistinct print, colored or poor quality illustrations and photographs, print bleedthrough, substandard margins, and improper alignment can adversely affect reproduction.

In the unlikely event that the author did not send UMI a complete manuscript and there are missing pages, these will be noted. Also, if unauthorized copyright material had to be removed, a note will indicate the deletion.

Oversize materials (e.g., maps, drawings, charts) are reproduced by sectioning the original, beginning at the upper left-hand corner and contiming from left to right in equal sections with small overlaps. Each original is also photographed in one exposure and is included in reduced form at the back of the book.

Photographs included in the original mamuscript have been reproduced xerographically in this copy. Higher quality $6^{\prime \prime} \times 9^{n}$ black and white photographic prints are available for any photographs or illustrations appearing in this copy for an additional charge. Contact UMI directly to order.

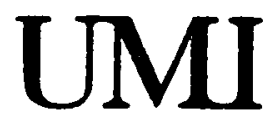

A Bell \& Howell information Company 300 North Zeeb Road. Ann Arbor. MI 48106-1346 USA $313: 761-4700 \quad 800: 521-0600$ 
- $\ldots . .$. 


\title{
EFFECTS OF OFF-HIGHWAY VEHICLES ON SEASONAL HOME RANGES AND DAILY ACTIVITY LEVELS OF BLACK-TAILED DEER
}

\author{
A Thesis \\ Presented to \\ The Faculty of the Department of Biological Sciences \\ San Jose State University
}

\author{
In Partial Fulfillment \\ of the Requirements for the Degree \\ Master of Science
}

by

Kristina Timmerman

May 1995 
UMI Number: 1374626

OMI Microform 1374626

Copyright 1995, by UMI Company. All rights reserved.

This microform edition is protected against unauthorized copying under Title 17, United States Code.

\section{UMI}

300 North Zeeb Road

Ann Arbor, MI 48103 
(C) 1995

Kristina Timmerman

ALL RIGHTS RESERVED 
APPROVED FOR THE DEPARTMENT OF BIOLOGICAL SCIENCES

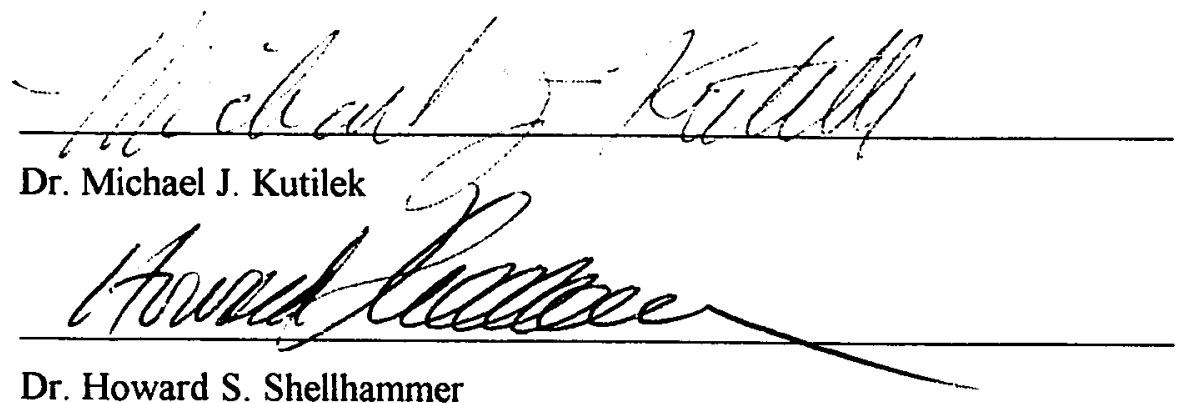

Dr. Howard S. Shellhammer

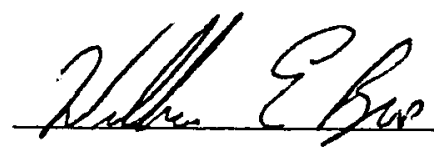

Dr. William E. Bros

APPROVED FOR THE UNIVERSITY

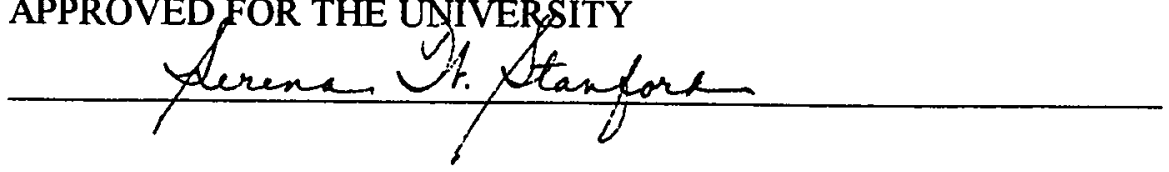




\section{ABSTRACT \\ EFFECTS OF OFF-HIGHWAY VEHICLES ON SEASONAL HOME RANGES AND DAILY ACTIVITY LEVELS OF BLACK-TAILED DEER \\ by Kristina Timmerman}

The seasonal home range and daily activity of adult female black-tailed deer (Odocoileus hemiomus columbianus) were compared between two study sites in 1992 . Radio-collared deer were monitored in Hollister Hills State Vehicular Recreation Area (HHSVRA), where the average number of off-highway vehicles (OHV) were 64.4 per weekday and 396.0 per weekend day and in Renz Ranch, where all public vehicular traffic is prohibited. Home ranges and core areas were estimated by the adaptive kernel and minimum convex polygon methods. The minimum convex polygon estimates are included for comparative purposes only and were not incorporated into the analyses. Activity was measured by calculating the percentage of active collar signals per day. There was no difference between study sites in seasonal home range or core area estimates. Annual mean daily activity was significantly higher on HHSVRA (71.6\%) when compared to Renz Ranch (57.9\%). HHSVRA deer had two of their three lowest mean daily activity levels during the weekend when $\mathrm{OHV}$ traffic was high. A strong negative correlation was found between the mean daily activity levels of HHSVRA deer and mean daily OHV traffic levels. There was no correlation between activity levels for deer on Renz Ranch deer and OHV traffic levels. 


\section{ACKNOWLEDGMENTS}

For their endless patience, guidance and editing expertise throughout this project, I thank my committee members, Drs. Michael J. Kutilek, Howard S.

Shellhammer and William E. Bros. In particular, I thank Dr. Michael J. Kutilek for providing me with the opportunity to pursue this academic goal.

The project was funded by the California Department of Parks and Recreation. Ken Anderson lent logistical and organizational support. Ralph Fairfield and his staff at Hollister Hills State Vehicular Recreation Area were always ready to help in any way. The field project would not have been feasible without the field assistance of Marcia Stickler, Andrea Webber and Brett Dixon. I thank Bob Ferris for handing over the project reins so smoothly and graciously. Fellow students Emily Buffin, Rob Burton, Kit Crump, Allegra Bukojemsky and Kathy Wade gave freely of their time and friendship for which I am deeply grateful. And finally, I thank my endlessly patient husband Dana for his love, friendship, computer wizardry and unflagging belief in my abilities. 


\section{TABLE OF CONTENTS}

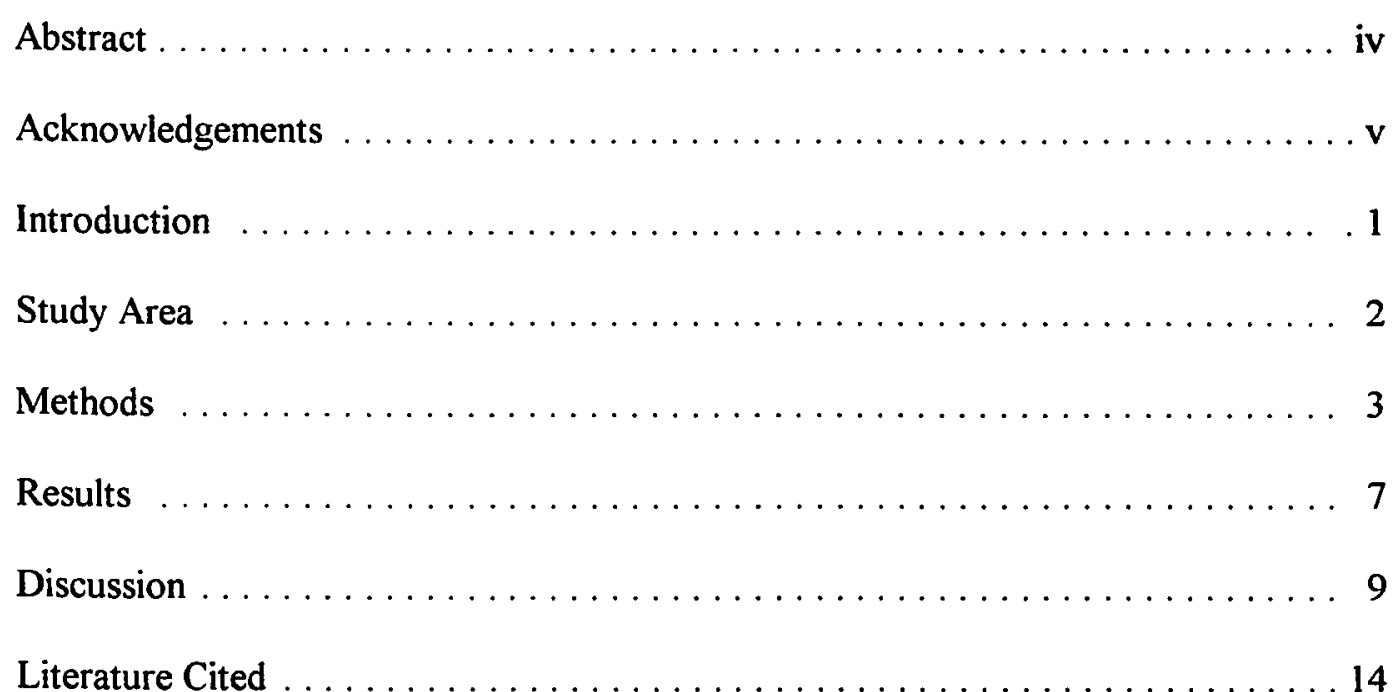




\section{LIST OF TABLES}

Table 1 Mean home range and core areas (ha) for black-tailed deer on Hollister Hills State Vehicular Recreation Area (HHSVRA) and Renz Ranch (RR), California, 1992. Sample size refers to number of deer in each study area. The $p$ value is for independent t-tests comparing $95 \%$ home range and $50 \%$ core area sizes between the two study areas. Minimum Convex Polygon data were supplied for comparative purposes only and were not included in the analysis 


\section{LIST OF FIGURES}

Figure 1 Comparison of black-tailed deer mean daily activity levels on Hollister Hills State Vehicular Recreation Area and Renz Ranch, California with mean daily $\mathrm{OHV}$ traffic levels, $1992 \ldots \ldots \ldots \ldots \ldots$ 


\section{INTRODUCTION}

Black-tailed deer (Odocoileus hemiomis columbiamus) may respond to offhighway vehicle (OHV) recreational activity by changing their pattern of home range use. In a previous study on Hollister Hills State Recreational Area (HHSVRA), Ferris (1989) reported that deer tended to leave HHSVRA during periods of peak OHV use, typically on weekends and returned to the area by midweek. Yarmoloy et al. (1988) found that deer exposed to OHV use for the first time left their home range and used cover more frequently, but they quickly habituated to the traffic pattern and returned to pre-harassment use of home range and cover.

Ungulate response to vehicles other than OHV's range from no detectable change to significant differences in behavior and movement. Carbaugh et al. (1975) and Adams (1981) reported that highway traffic was not a major disturbance factor on deer distribution in areas adjacent to interstate highways. In Arizona, desert mule deer initially reacted to low-flying aircraft but quickly habituated to the disturbance (Krausman et al. 1983). In Minnesota's Mille Lacs Wildlife Management Area, where snowmobiling is prohibited, Dorrance et al. (1975) found white-tailed deer increased their home-range size and movements between relocations with an increase in snowmobile activity trials. The same authors reported that deer in St. Croix State Park, where snowmobiling is permitted, showed no change in the same factors with similar snowmobile trials. 
In this study, I investigated black-tailed deer response to OHV use by measuring home range size and mean daily activity levels on HHSVRA and on the Renz Ranch, an adjacent parcel of land owned by the Department of Parks and Recreation but closed to OHV traffic. The objective of this study was to determine if deer home range size and mean daily activity levels differed significantly between the two study areas.

\section{STUDY AREA}

Hollister Hills State Vehicular Recreation Area (HHSRVA) and Renz Ranch (RR) are located in the Gabilan Range approximately 120 kilometers south of San Francisco in San Benito County, California. HHSRVA is a 1356 ha unit of the State Park system. The land was privately operated as a motorcycle riding facility until the State of California purchased the ranch in 1975 (California Department of Parks and Recreation 1978) and opened it to motorcycle and all-terrain vehicle recreational riding. Renz Ranch is an undeveloped state park property directly north and adjacent to HHSRVA. This 1300 ha property was a working cattle ranch from the late 1800 's through August 1991, when all livestock were removed. Occasional park personnel patrols and this project's field crew were the only known humans to frequent the area.

The dominant vegetation types found on HHSVRA were chaparral characterized by chamise (Adenostoma fasiculatum) and toyon (Heteromeles 
arbutifolia), riparian oak-woodland characterized by sycamore (Platamus racemosa), alder (Almus rhombifolia) and coast live oak (Quercus agrifolia) and oak savannah, characterized by coast live oak, blue oak (Q. douglasii), wild oats (Avena fatua) and ripgut grass (Bromus rigidus). The vegetation types on $\mathrm{RR}$ were primarily oak savannah with some chaparral and riparian oak-woodland. Elevation within the study area ranges from $240-740 \mathrm{~m}$ above mean sea level. The climate is Mediterranean, characterized by cool, wet winters and hot, dry summers. For a more detailed habitat description, see Kutilek et al. (1991).

\section{METHODS}

During the previous study by Ferris (1989), deer were captured using modified Clover traps (Clover 1956) or tranquilizer darts and fitted with radio-collars equipped with motion sensors (Telonics Inc., Tempe AZ). The motion sensor responds to animal movement and produces a fast or slow pulse rate indicating an active or inactive animal. One adult female deer was captured on 2 September 1988 and 10 adult females were captured between 5 September 1990 and 8 December 1991 (Timmerman et al. 1992). Each deer was defined as a HHSVRA animal or a RR animal if more than $50 \%$ of their locations were in one of these study areas.

During the study period, 1 January 1992 through 24 December 1992, I determined seasonal divisions based on deer behavior. The year was divided into four 
seasons: 1 January to 31 March (winter), 1 April to 14 June (spring), 15 June to 18 September (summer) and 19 September to 24 December (fall).

Each deer was tracked by radio an average of 2.5 times per week with a handheld directional 2-element Yagi antenna and a Telonics TR2 receiver. Field personnel used triangulation to obtain each deer location (Mech 1983), which was subsequently plotted on a USGS 7.5 minute Hollister quadrangle using the Universal Transverse Mercator (UTM) projection. We determined position accuracy by using one of the four following techniques during each relocation: 1) visual sighting of deer, 2) deer screened by vegetation but field personnel able to receive the signal with only the TR2 receiver box, 3) deer screened by vegetation but field personnel able to receive the collar signal with the antenna lead, 4) deer screened by vegetation or at a distance that precluded any of the previous techniques. Therefore, 2-4 signal directions were made to triangulate on animal's position. I field tested the reception distance of technique 2 and 3 and found that the biologist had to be within $2 \mathrm{~m}$ and $10 \mathrm{~m}$ for each technique, respectively. Accuracy was not measured on locations obtained by triangulation. However, the error polygons are not expected to differ between the study sites. Time between deer locations ranged from 1-12 days. I used the $\mathrm{t}^{2} / \mathrm{r}^{2}$ ratio (Schoener 1981) modified by Swihart and Slade $(1985,1987)$ to statistically determine if locations were temporally independent or dependent. If data were found to be statistically dependent, I randomly selected and deleted locations to obtain statistical independence. There was no statistical independence for three deer in spring 1992; 
hence these animals were excluded from the spring season home range analysis. This serial correlation index is part of the microcomputer Program Home Range analysis package (Ackerman et al. 1990). All radio-collared deer were located a minimum of 30 times per season (Worton 1987).

Home-range sizes were estimated using the adaptive kernel method and the minimum convex polygon method (MCP) with the microcomputer program CALHOME (Baldwin and Kie 1992). Grid cell size has less influence on the adaptive kernel home-range estimates than the harmonic mean estimates, therefore, it is the recommended method of non-parametric home-range analysis (Larkin and Halkin 1994, Heinemeiyer 1993, Baldwin and Kie 1992, Worton 1989). Minimum Convex Polygon is the most commonly reported home range analysis method (Baldwin and Kie 1992); therefore, home range and core area location data were analyzed using this method for comparison to other studies (Larkin and Halkin 1994, Baldwin and Kie 1992). For both methods, home-range size estimates are reported as $95 \%$ utilization distribution contours and core areas are reported as $50 \%$ utilization distribution contours. Grid density was set automatically by CALHOME (Baldwin and Kie 1992).

Annual and seasonal daily activity were measured by recording deer radio-collar signals (active vs. inactive) and day of week with each deer relocation. Daily activity is reported as the percentage of active collars per day. Because OHV use on HHSVRA is permitted only during daylight hours, I pooled deer activity data by day of week (Monday-Sunday) so they were comparable to OHV traffic levels. Therefore, activity 
data were pooled by day of week within each area and the daily activity level was compared between the two areas.

Throughout the year, weekend OHV traffic levels were relatively heavier $(\bar{y}=396.0$ OHV's / weekend day $)$ than weekday OHV traffic levels $(\bar{y}=64.4$ OHV's / weekday ). To test whether heavy or light $\mathrm{OHV}$ traffic levels influence daily deer activity, I pooled HHSVRA and RR activity data by weekends (Saturday-Sunday) and weekdays (Monday-Friday) and compared them to OHV weekend/weekday traffic levels.

Home-range size and core area estimates and activity data were tested for significant differences between HHSVRA and RR using an independent t-test (Zar 1974, Williams 1993). When variances between samples were unequal, I used the Mann -Whitney U statistic (Zar 1974, Williams 1993). Differences were considered significant when $p \leq 0.05$. I also measured the relationship between daily traffic levels and mean percent daily collar activity using Pearson Product Moment Correlation Coefficient (Zar 1974, Williams 1993). A correlation was considered significant when $r \geq 0.70$. OHV traffic levels were determined by gate receipts. 


\section{RESULTS}

Home Range Size

I recorded 1218 locations for 11 deer on the HHSRVA and Renz Ranch between 1 January 1992 and 24 December 1992 . Of the 1218 locations, $75 \%$ were determined using detection techniques 1-3 and the remaining locations were determined using triangulation. Two deer were not included in the home range analysis because they used both study areas for less than $30 \%$ of their relocations. Midway through the study, two mortalities from predators reduced the number of radio-collared deer available for analysis to 7 animals. I found that deer shifted their home ranges seasonally and, therefore, home range and core area analysis for each study site have different numbers of individuals and sample sizes for each season.

The home range and core areas for nine deer were estimated using 959 locations. Sample sizes ranged between 30-40 locations for each deer per season. Seasonal home range and core area estimates varied by individuals on both study areas but there was no significant difference in any of the seasonal home range or core area estimates of the HHSRVA and Renz Ranch (Table 1).

Activity

Annual mean daily activity was found to be significantly higher in the HHSRVA (70.0\%) than in Renz Ranch $(62.1 \%, p=0.008)$. To determine if the difference in activity rate was a result of sample size differences (Renz $\operatorname{Ranch} N=840$, 


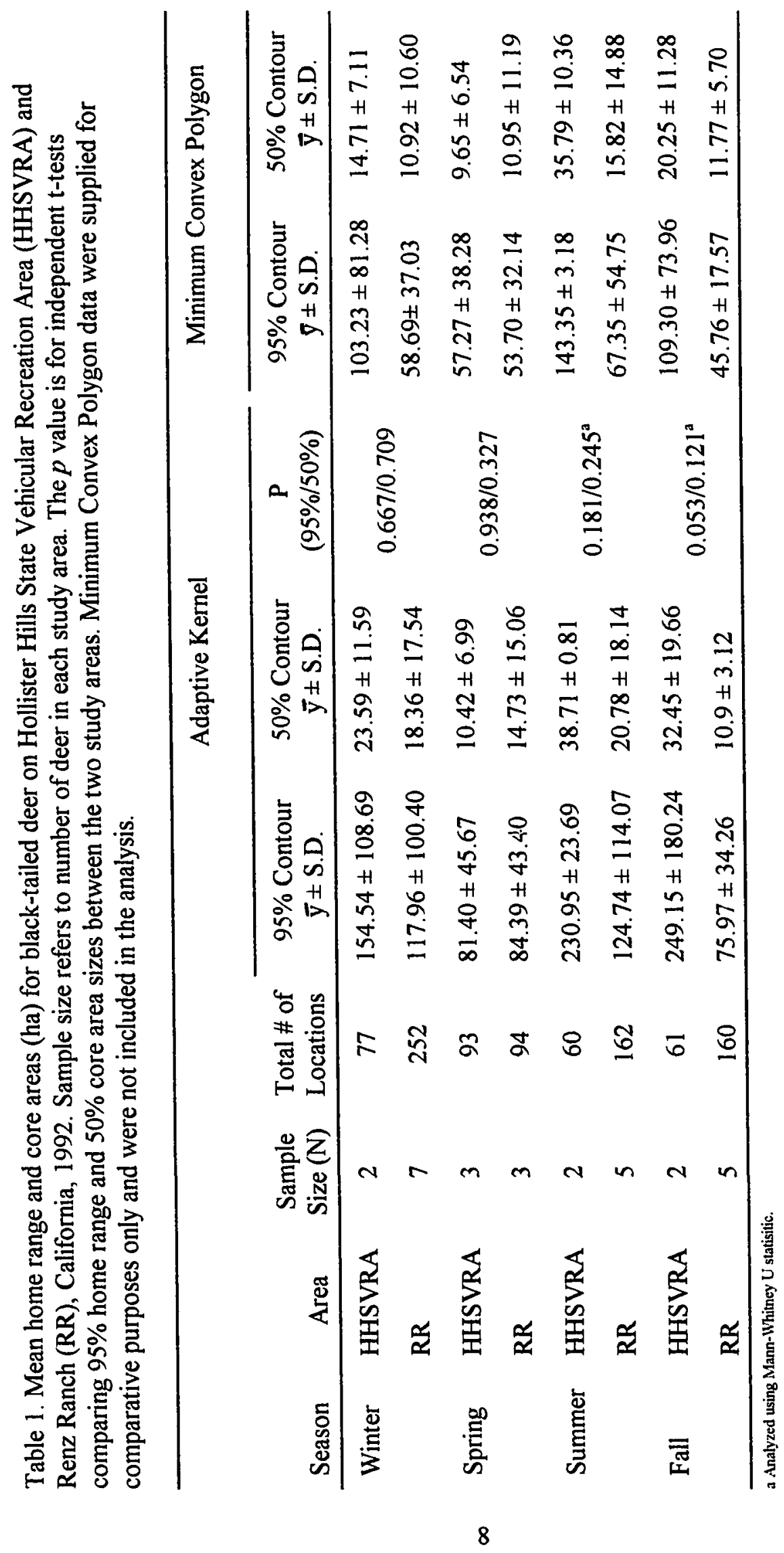


HHSRVA $\mathrm{N}=378$ ), I randomly subsampled the Renz Ranch activity data so that each area had a similar sample size $(\mathrm{N}=382, \mathrm{~N}=378$, respectively). Using the subsampled data, mean daily activity was still significantly higher in the HHSRVA as compared to Renz Ranch (57.9\% and $71.6 \%$, respectively, $p=0.001)$. The subsampled data were used for all subsequent analyses. When seasonal mean daily activity data were compared between the study sites, activity was significantly higher for all seasons in HHSVRA $(p=0.008)$

I found a significant difference in weekend and weekday OHV levels $(p=$ 0.001 ), so mean daily activity data of both study sites were compared with mean daily OHV traffic levels. There was no correlation between the activity rate of Renz Ranch deer and OHV traffic levels $(r=0.028)$ but a significant negative correlation was found between the activity rate of HHSVRA deer and OHV traffic levels $(r=-0.694)$ (Fig. 1).

\section{DISCUSSION}

The level and pattern of OHV use in HHSVRA appears to have had no effect on seasonal home range and core area sizes of black-tailed deer. These results are consistent with previous studies. Ferris (1989) compared deer home range size on the HHSVRA with those of other studies and found no significant difference.

There are two possible explanations for the similarity in home range sizes on the 


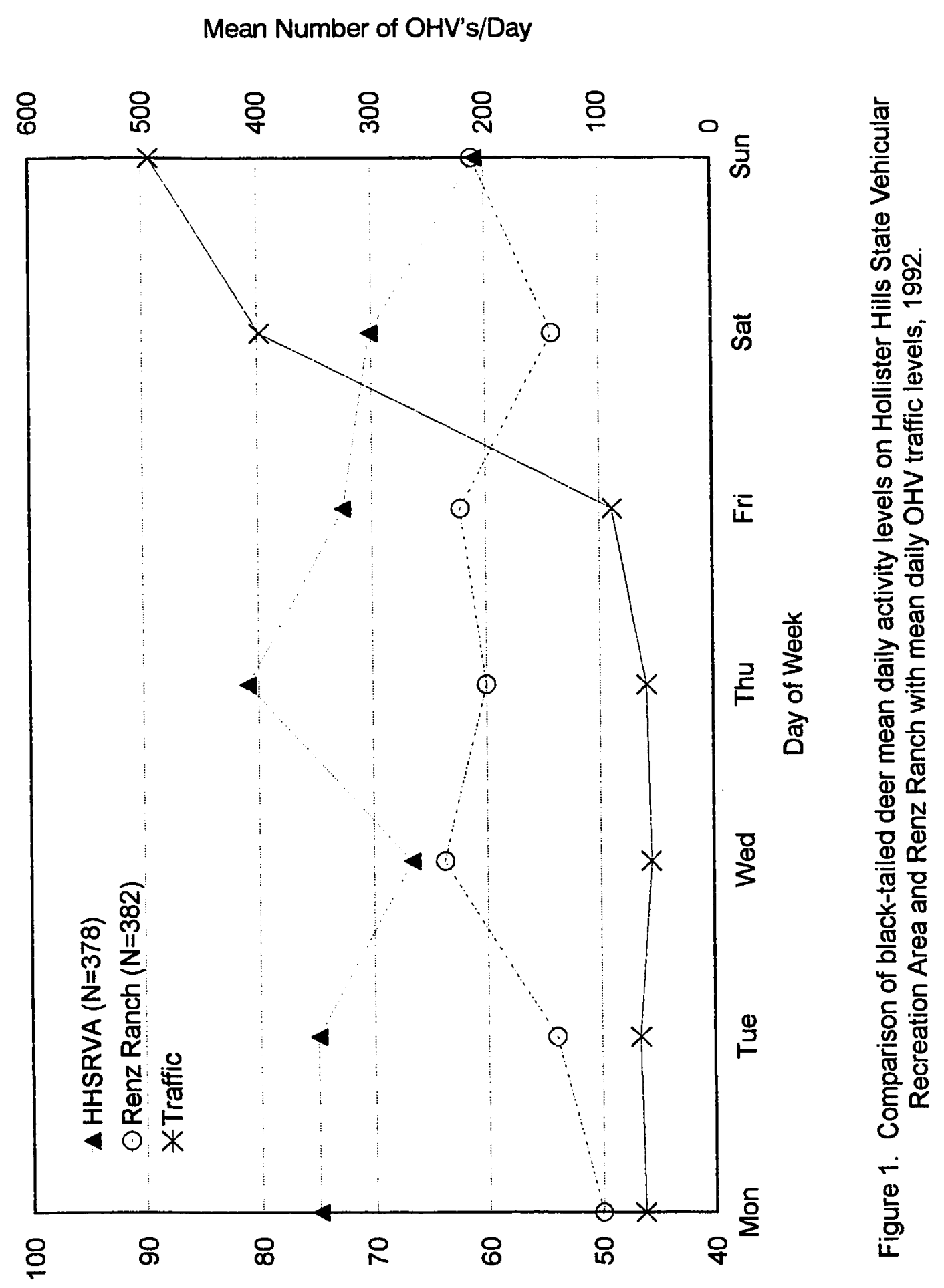

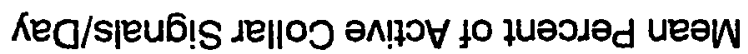


two study sites. First, each dominant habitat type found in the HHSVRA (chaparral, riparian-oak woodland and oak savannah) has substantial amounts of shrub cover. Particularly in chaparral, shrubs act as physical barriers which limit OHV traffic to established trails and, therefore, provide deer with undisturbed bedding areas.

Throughout the study period, field personnel observed radio-collared deer bedded in shrubs directly adjacent to heavily travelled OHV trails. Second, Yarmoloy et al. (1988) reported that deer changed their use of home ranges only when actively pursued by OHV's. Field personnel never observed OHV riders actively pursuing deer in the HHSVRA. The fact that deer were found in the riding areas during peak traffic periods and that they were not chased by OHV's indicates that the animals were habituated to the OHV traffic pattern of this this park.

I found that deer on the HHSVRA maintained a significantly higher mean daily activity levels as compared to Renz $\operatorname{Ranch}$ deer $(\bar{y}=71.61, \bar{y}=57.90$ respectively). A significant negative correlation between $\mathrm{OHV}$ traffic levels and mean daily activity levels for deer in HHSVRA $(r=-0.694)$ suggests that park deer should be least active during the weekends when OHV traffic levels are at a weekly peak. Two of the three lowest mean daily activity levels on the HHSVRA occur on the weekend (Fig. 1).

Other studies have reported detrimental effects on an animal's health and reproductive fitness as a result of human disturbance (Geist 1979). The significantly higher mean daily activity measured on HHSVRA may have a deleterious effect on the health and reproduction of HHSVRA deer. Yarmoloy et al. (1988) reported that the 
reproductive success of 3 females declined from 1.33 young per female to 0.33 young per female in the year following experimental ATV harassment trials. Females exposed to ATV traffic trials but not actively pursued showed no significant change in the young per female ratio.

We tracked reproduction through field observations of pregnant deer and subsequent fawn associations. Seven of 9 radio-collared deer produced 10 young during the spring of 1992. Deer in both HHSVRA and Renz Ranch had young-female ratios greater than $1(1.75,1.2$ respectively), a higher ratio than the non-pursued deer reported by Yarmoloy et al. (1988). The higher activity measured on HHSVRA does not appear to have a detrimental effect on deer reproductive rates. To determine if there are other physiological or metabolic requirements as a result of the higher activity on HHSVRA, additional studies would be necessary.

I found that deer used their home range in a non-uniform pattern on both study sites but they did not leave the park during peak OHV traffic levels as Ferris and Kutilek reported (1989). Deer tended to use an area intensively for $1-3$ weeks and then moved to a new area of intensive use. The movement between areas of intensive use occurred on both weekdays and weekends. This pattern has been observed for deer in other areas (Eberhardt et al. 1984, Dasman and Taber 1956).

Black-tailed deer appear to have habituated to cyclical OHV traffic levels in HHSVRA. The only significant difference measured between the two study sites was a higher mean daily activity level for deer on HHSVRA. Based on the high young-female 
ratio (1.75), the higher activity level does not appear to have serious detrimental reproductive effects. 


\section{LITERATURE CITED}

Ackerman, B.B., F.A. Leban, M.D. Samuel, and E.O. Garton. 1990. User's manual for program HOME RANGE. Second edition. Technical Report 15, Forestry, Wildlifeand Range Experiment Station, University of Idaho, Moscow, ID. 80pp.

Adams, L.W. 1981. Effects of Highways on Wildlife. Urban Wildlife Research Center. PB83-119628. 133pp.

Baldwin, J. and J. Kie. 1992. Program CALHOME (CALornia HOMErange). Calif. Fish and Game and USFS For. Sci. Lab., Fresno, CA. Unpublished Report. $17 \mathrm{pp}$.

Carbaugh, B., J.P.Vaughn, E.D. Bellis and H.B. Graves. 1975. Distribution and activity of white-tailed deer along an interstate highway. J. Wildl. Manage. 39:570-580.

California State Department of Parks and Recreation. 1978. Hollister Hills State Vehicular Recreation Area resource management plan, general development and environmental impact. Unpublished Report. 127pp.

Clover, M.R. 1956. Single gate deer trap. Fish and Game, 42:199-201.

Dasmann, R.F. and R.D. Taber. 1956. Behavior of Columbian black-tailed deer with reference to population ecology. J. Wildl. Manage. 37:143-164.

Dorrance, M.J., P.J.Savage, and D.E. Huff. 1975. Effects of snowmobiles on whitetailed deer. J. Wildl. Manage. 39:563-569.

Eberhardt, L.E., E.E. Hanson and L.L.Cadwell. 1984. Movement and activity patterns of mule deer in the sagebrush-steppe region. J. Mamm. 65:404-409.

Ferris, R.M. 1989. Responses of black-tailed deer to off-highway vehicles. M.A. Thesis, San Jose State University, San Jose, CA. 14 pp.

Geist, V. 1979. Life strategies, human evolưiion, environmental design. SpringerVerlag, New York, N.Y. 496pp. 
Heinemeyer, K.S. 1993. Temporal dynamics in the movements, habitat use, activity and spacing of reintroduced fishers in Northwestern Montana. M.S. Thesis. University of Montana, Missoula, MT. 158pp.

Krausman, P.R., B.D. Leopold and D.L. Scarbrough. 1986. Desert mule deer response to aircraft. Wildl. Soc. Bull. 14(1):68-70.

Kutilek, M.J., H. Shellhammer and W. Bros. 1991. Inventory, wildlife habitat protection program and monitoring program for Hollister Hills State Vehicular Recreation Area, California. Unpublished Report. San Jose State University. $81 \mathrm{pp}$.

Larkin, R.P. and D. Halkin. 1994. Wildlife Software: a review of software packages for estimating animal home ranges. Wildl. Soc. Bull. 22:274-287.

Mech, L.D. 1983. Handbook of animal radio-tracking. Univ. of Minn. Press, Minneapolis, MN. 197pp.

Schoener, T.W. 1981. An empirically based estimate of home range. Theoret.. Pop. Biol. 20:281-325.

Swihart, R.K. and N.A. Slade. 1985. Testing for independence of observations in animal movements. Ecol. 66:1176-1184.

. 1987. A test of independence of movements as shown by live-trapping. Am. Midl. Nat. 117:204-207.

Timmerman, K., M.J. Kutilek, R.M. Ferris, and K.E. Duncan. 1992. Black-tailed deer responses to three types of land use at Hollister Hills State Vehicular Recreation Area, Hollister, California. Unpublished Progress Report. San Jose State University, San Jose, CA. 18pp.

Williams, B. 1993. Biostatistics; concepts and applications for biologists. Chapman \& Hall, London, England. 201pp.

Worton, B.J. 1987. A review of models of home range analysis for animal movements. Ecol. Model. 38:277-298.

1989. Kernel methods for estimating the utilization distribution in homerange studies. Ecol. 70:164-168. 
Yarmoloy, C., M. Bayer and V. Geist. 1988. Behavior response and reproduction of mule deer does following experimental harassment with an all-terrain vehicle. Can. Field Nat. 102: 425-429.

Zar, J.H. 1974. Biostatistical analysis. Prentice-Hall, Englewood Cliffs, N.J. 620pp. 